\title{
SIMULTANEOUS PRODUCTION OF AMYLASE AND PROTEASE BY AEROMONAS HYDROPHILA PC5, A PSYCHROTROPHIC BACTERIUM
}

\author{
LOKENDRA SINGH,* MUSTOORI SAI RAM, MUKESH KUMOR AGGARWAL, \\ AND SYED IMTIAZ ALAM
}

Defence Research \& Development Establishment, Gwalior-474 002, India

(Received December 6, 1993; Accepted August 19, 1994)

\begin{abstract}
Aeromonas hydrophila PC5, a soil isolate, produced amylase and protease on a variety of substrates. The highest titers of both enzymes were observed with casein at $20^{\circ} \mathrm{C}$ and at $\mathrm{pH}$ 7.0. Unlike amylase, the protease was thermostable and retained about $50 \%$ activity at $60^{\circ} \mathrm{C}$ after $120 \mathrm{~min}$ of exposure. Of the metal ions tested, only protease was stimulated by 10 $\mathrm{mM} \mathrm{Fe} \mathrm{F}^{+2}$. EDTA and iodoacetamide inhibited both of the enzymes. Partial purification with DEAE-cellulose revealed that the enzyme complex consists of an $\alpha$-amylase, a $\beta$-amylase and a metalloprotease.
\end{abstract}

Gram-positive bacteria mainly belonging to the genus Bacillus have been exploited to produce extracellular commercial enzymes such as proteases, amylases and lipases $(13,18)$. Among Gram-negative bacteria, only a few species such as Klebsiella aerogenes (for pullulanase) are used for enzyme production (13). This reflects the paucity of true extracellular enzymes in these bacteria, and the difficulty and expense of recovering periplasmic enzymes on a commercial scale.

Most of the above work has been focussed on mesophilic and thermophilic bacteria $(14,16,17)$. Little attention has been paid to bacteria which can grow at low temperatures perhaps because of the slow growth rate, and difficulty in handling these bacteria (11). Psychrotrophs have been less frequently studied, mainly as contaminants in dairy products $(21)$. It has been shown that some psychrotrophs produce thermostable enzymes which may have industrial applications $(7,8)$.

In our laboratory, we have recently isolated a Gram-negative psychrotrophic bacterium, Aeromonas hydrophila PC5 from soil samples from Leh (4,000 m above sea level), India where the temperature varies from -25 to $+25^{\circ} \mathrm{C}$. The strain produces an active extracellular enzyme complex consisting of amylase and prote-

\footnotetext{
* Address reprint requests to: Dr. Lokendra Singh, Defence Research \& Development Establishment, Tansen Road, Gwalior-474 002, India.
} 
ase; both enzymes are produced together during growth on a variety of substrates.

Though $A$. hydrophila has been reported to be an opportunistic pathogen to fish and humans, the present strain was found to be nonpathogenic to fish and snails. It also appears to be nonpathogenic to humans due to its poor ability to grow at $37^{\circ} \mathrm{C}$. Its ability to produce amylase and protease at low temperatures is of high interest in simultaneous saccharifications and fermentation of starch to ethanol in combination with yeast. This is of special importance in the beer industry where fermentation is carried out at low temperatures. Further, the enzymes may be of great use in removing the chill haze (due to protein and starch) of beers, and in biodegradation of waste materials at low temperatures. We report here on the preliminary experiments conducted to find out the optimum conditions for enzyme production, activity and regulation in $A$. hydrophila PC5.

\section{MATERIALS AND METHODS}

Culture conditions. The organism was grown in 500-ml Erlenmeyer flasks containing $250 \mathrm{ml}$ of defined medium with the following constituents in $\mathrm{g}^{-1}$ : $\mathrm{KH}_{2} \mathrm{PO}_{4}, 1.5 ; \mathrm{K}_{2} \mathrm{HPO}_{4}, 1.0 ;\left(\mathrm{NH}_{4}\right)_{2} \mathrm{SO}_{4}, 2.0 ; \mathrm{MgSO}_{4}, 0.8 ; \mathrm{CaCl}_{2}, 0.1$; yeast extract, 2.0; sodium citrate, 1.0. Unless otherwise specified the carbon source used was $4 \mathrm{~g} l^{-1}$ glucose or casein (Hammerstein). After sterilization, the medium was inoculated with exponentially growing culture $\left(10^{4} \mathrm{cfu}\right.$ per liter) and the flasks were incubated on a shaker at $20^{\circ} \mathrm{C}$ for 3 to 5 days. Later the medium was centrifuged at 7,000 rpm for $30 \mathrm{~min}$ and the supernatant was used as the enzyme source.

Thermal stability studies. Thermal stability of the enzymes was studied by exposing the enzyme to 50 to $70^{\circ} \mathrm{C}$ for $5,10,20,30,60$ and $120 \mathrm{~min}$, after which the activity was measured at $37^{\circ} \mathrm{C}$ with casein and soluble starch for protease and amylase respectively.

Inhibition studies. Effect of different metal ions and protein denaturants (Table 3 ) on enzyme activity was studied by adding appropriate concentrations to the enzyme before incubating with the substrate.

Enzyme assay.

Protease: One milliliter of the culture supernatant was added to $1 \mathrm{ml}$ of $1 \%$ casein (Hammerstein) in $2 \mathrm{ml}$ of $0.1 \mathrm{M}$ Tris- $\mathrm{HCl}$ buffer, $\mathrm{pH} \mathrm{8.0,} \mathrm{and} \mathrm{incubated} \mathrm{at}$ $37^{\circ} \mathrm{C}$ for $1 \mathrm{~h}$. The reaction was stopped by adding $2 \mathrm{ml}$ of $20 \%$ trichloroacetic acid. After $30 \mathrm{~min}$, the precipitate was pelletted by centrifugation at $5,000 \mathrm{rpm}$ for $20 \mathrm{~min}$ and the end products in the supernatant were determined by the folin-phenol reagent. One unit was defined as the amount of enzyme required to release $1 \mu \mathrm{mol}$ of tyrosine equivalents under assay conditions.

Amylase: The activity was measured by adding $1 \mathrm{ml}$ of the enzyme with $1 \mathrm{ml}$

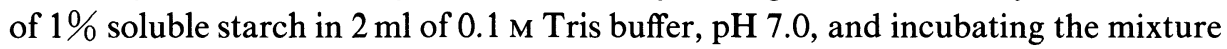
for $30 \mathrm{~min}$ at $37^{\circ} \mathrm{C}$. After incubation, $0.5 \mathrm{ml}$ of sample was added to a test tube containing $1 \mathrm{ml}$ of $1 \mathrm{~N} \mathrm{HCl}$ followed by the addition of $5 \mathrm{ml}$ of iodine reagent $(0.1 \%$ iodine in $0.5 \% \mathrm{KI}$ ). The intensity of blue color was measured at $660 \mathrm{~nm}$ using a 
spectrophotometer. One unit of amylase was defined as the amount of enzyme required to decrease the optical density of the blue color of mixture by $0.01 \mathrm{~min}^{-1}$ (equivalent to $12.5 \mu \mathrm{g}$ starch degraded). Another $0.5 \mathrm{ml}$ each of the enzyme and substrate mixture was used to measure glucose released by the glucose oxidase method (Ranbaxy Chemicals, India) and total reducing sugars released by dinitrosalicylic acid (DNS) reagent and the results were later confirmed by HPLC (UV detector) using $80 \%$ acetonitrile as the mobile phase.

Purification of the enzymes. After growth, the broth was centrifuged at 7,000 $\mathrm{rpm}$ for $30 \mathrm{~min}$, and the protein was precipitated with $60 \%$ ammonium sulfate. The precipitate was allowed to settle at $4{ }^{\circ} \mathrm{C}$ for $2 \mathrm{~h}$ and pelletted out by centrifugation. The pellet was dissolved in $0.1 \mathrm{M}$ Tris buffer, $\mathrm{pH} 7.0$, and dialyzed against distilled water overnight at $4^{\circ} \mathrm{C}$. The dialyzed suspension $(2 \mathrm{ml})$ was applied to DEAEcellulose ion exchange column and the proteins were eluted in a linear gradient of $0.5 \mathrm{M} \mathrm{KCl}$. The fractions $(5 \mathrm{ml})$ were collected and protein concentration was monitored by absorbance at $280 \mathrm{~nm}$. Later the enzyme activity in the fractions was measured as described above. Sodium dodecyl sulfate polyacrylamide gel electrophoresis (SDS-PAGE) of purified samples was carried out by the method of Blackshear (4). To determine the activity of the enzymes in gels, substrateimpregnated gel electrophoresis with crude enzyme preparations was carried out using $10 \%$ gel containing $0.5 \%$ gelatin/starch (10). Later, the gels were incubated in $0.1 \mathrm{M}$ Tris buffer ( $\mathrm{pH} \mathrm{7.5)}$ at $37^{\circ} \mathrm{C}$ for $2 \mathrm{~h}$. The amylase activity was detected by staining the gel with iodine reagent while the protease activity was detected by staining the gel with $0.1 \%$ Coomassie Blue and destaining with $10 \%$ acetic acid.

All experiments were performed in duplicate on two different occasions.

\section{RESULTS}

\section{Production of amylase and protease}

The strain produced both amylase and protease on all the carbon sources tested (Table 1). As expected, the highest titers of protease were obtained on casein and the titers on other substrates remained more or less the same. Surprisingly, amylase was also expressed maximally on casein followed by glucose. Whereas, maltose and starch induced comparatively low levels of amylase.

\section{Effect of nitrogen and yeast extract on enzymes production}

Without yeast extract and nitrogen source, glucose supported little growth of

Table 1. Production of protease and amylase by Aeromonas hydrophila PC5 on different substrates (incubation at $20^{\circ} \mathrm{C}$ for 3 days).

\begin{tabular}{lcccc}
\hline & Glucose & Maltose & Starch & Casein \\
\hline Growth $(3 \times)($ OD $520 \mathrm{~nm})$ & 1.31 & 1.40 & 1.38 & 1.93 \\
Protease (units $\left.\mathrm{ml}^{-1}\right)$ & 5.70 & 4.93 & 5.31 & 7.93 \\
Amylase (units $\mathrm{ml}^{-1}$ ) & 3.10 & 2.42 & 2.63 & 3.71 \\
\hline
\end{tabular}


Table 2. Effect of nitrogen sources on growth and enzyme production by Aeromonas hydrophila (incubation at $20^{\circ} \mathrm{C}$ for 5 days).

\begin{tabular}{|c|c|c|c|c|}
\hline & Glucose & $\begin{array}{c}\text { Glucose } \\
+\left(\mathrm{NH}_{4}\right)_{2} \mathrm{SO}_{4}\end{array}$ & Casein & $\begin{array}{c}\text { Casein } \\
+\left(\mathrm{NH}_{4}\right)_{2} \mathrm{SO}_{4}\end{array}$ \\
\hline \multicolumn{5}{|l|}{ Without yeast extract } \\
\hline Optical density $(\times 10)$ & 0.08 & 0.28 & 0.48 & 0.60 \\
\hline \multicolumn{5}{|l|}{ Amylase } \\
\hline Units $\mathrm{ml}^{-1}$ & 1.2 & 2.8 & 3.2 & 3.2 \\
\hline Units $\mathrm{mg}^{-1}$ cell protein & 2.4 & 1.5 & 0.8 & 0.6 \\
\hline \multicolumn{5}{|l|}{ Protease } \\
\hline Units $\mathrm{ml}^{-1}$ & 8.0 & 9.7 & 10.4 & 10.1 \\
\hline Units $\mathrm{mg}^{-1}$ cell protein & 16.0 & 5.3 & 3.2 & 2.5 \\
\hline \multicolumn{5}{|l|}{ With yeast extract } \\
\hline Optical density $(\times 10)$ & 0.23 & 0.35 & 0.40 & 0.56 \\
\hline \multicolumn{5}{|l|}{ Amylase } \\
\hline Units $\mathrm{ml}^{-1}$ & 1.2 & 2.5 & 2.9 & 3.1 \\
\hline Units $\mathrm{mg}^{-1}$ cell protein & 0.8 & 1.1 & 1.1 & 0.8 \\
\hline \multicolumn{5}{|l|}{ Protease } \\
\hline Units $\mathrm{ml}^{-1}$ & 1.3 & 4.7 & 7.6 & 7.6 \\
\hline Units $\mathrm{mg}^{-1}$ cell protein & 0.9 & 2.0 & 2.7 & 2.0 \\
\hline
\end{tabular}

A. hydrophila whereas casein with ammonium sulfate supported the highest growth. Maximum titers $\mathrm{ml}^{-1}$ of amylase and protease were obtained on casein with or without ammonium sulfate (Table 2). However, the amylase yields $\mathrm{mg}^{-1}$ cell protein was about one and a half times to four times, and protease by about three to six times higher on glucose without nitrogen and yeast extract. Addition of yeast extract to glucose medium dramatically reduced the amylase yield $\mathrm{mg}^{-1}$ cell protein by about three times. However, the yeast extract had no appreciable effect on amylase yields in other combinations used. Interestingly, the addition of yeast extract to glucose with or without nitrogen resulted in a drastic fall in total yields of protease (both $\mathrm{ml}^{-1}$ and $\mathrm{mg}^{-1}$ cell protein).

\section{Time course of amylase and protease production}

The production of amylase and protease are independent of each other during growth. There is a steady increase in amylase titer with growth irrespective of substrate i.e. glucose and casein. Furthermore, amylase production continued even during the stationary phase. Whereas, protease was produced invariably during the exponential growth phase (Fig. 1).

\section{Effect of temperature and $p H$ on enzymes production}

The maximum growth of bacteria was observed between 15 to $20^{\circ} \mathrm{C}$ and the production of both the enzymes paralleled the growth. The amylase was detected in the temperature range of 5 to $35^{\circ} \mathrm{C}$ and it's titer increased with temperature up to $15^{\circ} \mathrm{C}$ and then decreased above $20^{\circ} \mathrm{C}$. Protease activity was not observed at 5 and $35^{\circ} \mathrm{C}$ even though there was little growth and the maximum yield of protease 


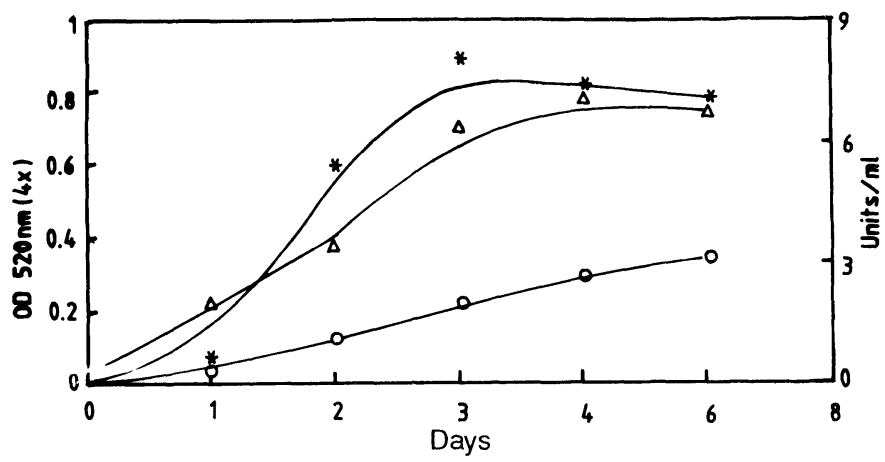

Fig. 1. Time course of enzyme production by Aeromonas hydrophila PC5. $\triangle$, growth; $\bigcirc$, amylase; $*$, protease.

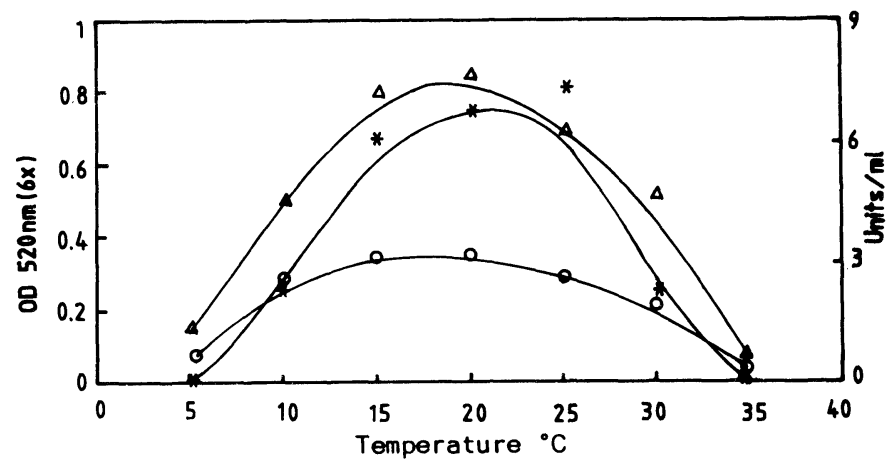

Fig. 2. Effect of temperature on growth and enzyme production by Aeromonas hydrophila PC5.

$\triangle$, growth; $\bigcirc$, amylase; $*$, protease.

was obtained at $20^{\circ} \mathrm{C}$ (Fig. 2). The optimum temperature for activity was $37^{\circ} \mathrm{C}$ for both the enzymes.

Both the enzymes were produced maximally at $\mathrm{pH} 7.0$ on casein and at $\mathrm{pH} 8.0$ on glucose. The optimum $\mathrm{pH}$ for amylase and protease for activity was 7.0 and 8.5 , respectively.

\section{Thermal stability}

The amylase was thermolabile and was completely inactivated at $50^{\circ} \mathrm{C}$ within $10 \mathrm{~min}$, whereas the protease was relatively thermostable and retained about 50 and $38 \%$ of its activity after exposing the enzyme to 60 and $70^{\circ} \mathrm{C}$ respectively for 120 min.

\section{Effect of metal ions and inhibitors}

In general, the amylase showed relatively more resistance to metal ions than 
Table 3. Effect of metal ions and inhibitors on amylase and protease activity.

\begin{tabular}{lccc}
\hline & \multirow{2}{*}{$\begin{array}{c}\text { Conc. } \\
(\mathrm{mM})\end{array}$} & Amylase activity & Protease activity \\
\cline { 3 - 4 } & & & \\
Metal ions & 10 & 96 & 92 \\
$\mathrm{Ca}^{2+}$ & 10 & 99 & 100 \\
$\mathrm{Mg}^{2+}$ & 10 & 90 & 176 \\
$\mathrm{Fe}^{2+}$ & 10 & 87 & 92 \\
$\mathrm{Co}^{2+}$ & 10 & 48 & 48 \\
$\mathrm{Cu}^{2+}$ & 10 & 70 & 64 \\
$\mathrm{Zn}^{2+}$ & 10 & 98 & 73 \\
$\mathrm{Mo}^{6+}$ & 10 & 96 & 84 \\
$\mathrm{Mn}^{2+}$ & 10 & 42 & 44 \\
$\mathrm{Ag}^{2+}$ & 10 & 70 & 44 \\
$\mathrm{Hg}^{2+}$ & & & 50 \\
Inhibitors & 10 & 20 & 98 \\
EDTA & 0.2 & 29 & 40 \\
SDS & 10 & 0 & 97 \\
Iodoacetamide & 5 & 95 & \\
PMSF & & & \\
\hline
\end{tabular}

$100 \%$ activity for amylase and protease were 3.5 and 6.7 units $\mathrm{ml}^{-1}$ respectively.

the protease. It retained about $90 \%$ activity in the presence of $\mathrm{Ca}^{2+}, \mathrm{Mg}^{2+}, \mathrm{Fe}^{2+}$, $\mathrm{Co}^{2+}, \mathrm{Mo}^{6+}$ and $\mathrm{Mn}^{2+}, \mathrm{Ag}^{2+}, \mathrm{Hg}^{2+}, \mathrm{Zn}^{2+}$ and $\mathrm{Cu}^{2+}$ inhibited the amylase and the order of toxicity was $\mathrm{Ag}^{2+}>\mathrm{Cu}^{2+}>\mathrm{Hg}^{2+}, \mathrm{Zn}^{2+}$. The protease activity was little affected by $\mathrm{Ca}^{2+}, \mathrm{Mg}^{2+}$ and $\mathrm{Co}^{2+}$. Unlike amylase, the presence of $10 \mathrm{mM} \mathrm{Fe}^{2+}$ resulted an increase of about $76 \%$ in its activity compared with the control. All other metals tested inhibited the protease and the order of toxicity was $\mathrm{Ag}^{2+}$, $\mathrm{Hg}^{2+}>\mathrm{Cu}^{2+}>\mathrm{Zn}^{2+}>\mathrm{Mo}^{6+}>\mathrm{Mn}^{2+}$ (Table 3).

The amylase was completely inactivated by iodoacetamide, and severely by EDTA and SDS, whereas the protease was inhibited considerably by iodoacetamide and EDTA. However, PMSF (phenylmethylsulfonylflouride) and SDS had no effect on protease activity (Table 3 ).

\section{Purification}

The data of substrate impregnated gel electrophoresis revealed that $A$. hydrophila produced two amylases and a protease (Fig. 3). DEAE-cellulose chromatography of crude enzyme also showed the presence of two amylases and a protease (Fig. 4). The protease and amylase 1 (fraction nos. 19 to 22) were eluted at 190 to $220 \mathrm{~mm} \mathrm{KCl}$, respectively, and could not be well separated. Amylase 1 showed an exo-acting pattern with slow blue value reduction against rapid reducing sugar release. Furthermore, the reducing sugars released were found to be maltose (by HPLC) indicating that the enzyme is $\beta$-amylase, whereas the amylase 2 (fraction no. 34) was eluted at $340 \mathrm{mM} \mathrm{KCl}$ and showed rapid blue value reduction with a slow increase in reducing power. The end products of starch hydrolysis included glucose, maltose and dextrins, as determined by glucose oxidase, DNS reagent and 


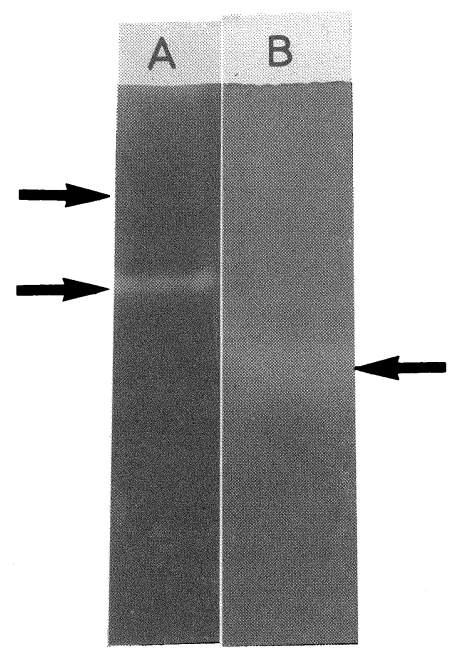

Fig. 3. Substrate-impregnated gel electrophoresis of crude enzyme complex of Aeromonas hydrophila.

(A) Amylase: top arrow indicates the incomplete hydrolysis of starch ( $\beta$-amylase) and bottom arrow indicates complete hydrolysis of starch ( $\alpha$-amylase). (B) Protease.

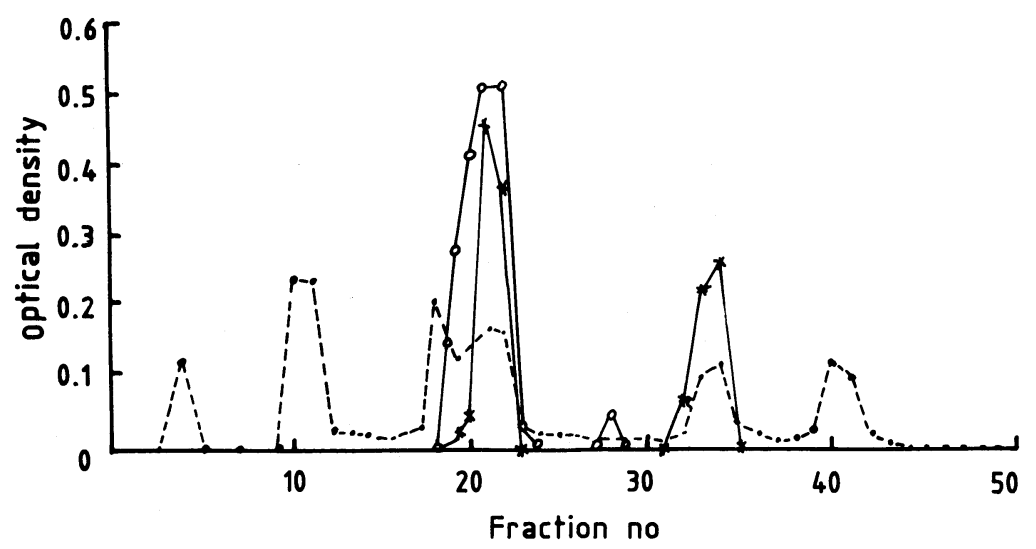

Fig. 4. DEAE-cellulose profile in enzyme complex of Aeromonas hydrophila.

$\bullet$, protein (absorption at $280 \mathrm{~nm}$ ); $*$, reducing power (DNS reagent, absorption at $540 \mathrm{~nm}$ ); $\bigcirc$, protease (absorption at $660 \mathrm{~nm}$ ).

HPLC, indicate that the enzyme is $\alpha$-amylase (data not shown). SDS-PAGE of this amylase fraction revealed a single protein band with a molecular weight of 60,000 (Fig. 5). 
A B

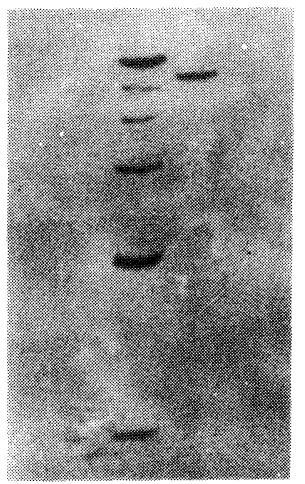

Fig. 5. Electrophoretic separation of $\alpha$-amylase by SDS-PAGE.

Lane A: molecular weight markers: BSA, 66,000; ovalbumin, 44,000; carbonic anhydrase, 29,000; lysozyme, 14,000. Lane B: $\alpha$-amylase.

\section{DISCUSSION}

A. hydrophila is reported to be pathogenic to fish and other aquatic fauna (2, $5)$. The pathogenecity was attributed to the production of extracellular hemolysins and proteases (3). Besides, A. hydrophila is reported to produce amylase (6). However the present strain, PC5, differed from standard strains in being psychrotrophic, unable to grow at $37^{\circ} \mathrm{C}$ and being non-pathogenic to fish and snails.

The strain PC5 produced an active enzyme complex consisting of an $\alpha$ amylase, $\beta$-amylase and a protease simultaneously on a wide variety of substrates. Interestingly, the amylase was expressed in higher yields on glucose (which is a strong catabolite repressor of amylase) than maltose and starch.

The strain grew well in defined medium with glucose as the sole carbon source (with ammonium) devoid of yeast extract but its presence enhanced the cell growth. The highest yields $\left(\mathrm{mg}^{-1}\right.$ cell protein) of amylase and protease were observed on glucose without nitrogen source although it supported little growth. Addition of nitrogen sources (ammonium sulfate or yeast extract) reduced the enzyme yields drastically. Thus nitrogen starvation is an important factor in governing the enzyme production in the present strain. Inhibition of protease by ammonia has been reported in Vibrio alginolyticus, Aeromonas hydrophila and Pseudomonas aeruginosa $(9,12,20)$.

Although the optimum temperature for growth and enzyme production remained between 20 to $25^{\circ} \mathrm{C}$, the optimum temperature for enzyme activity was 37 ${ }^{\circ} \mathrm{C}$ for both amylase and protease. The protease retained about $87 \%$ activity at 60 ${ }^{\circ} \mathrm{C}$ compared to $50 \%$ activity reported for $B$. amyloliquifaciens at the same temperature for $15 \mathrm{~min}$ (13). The reasons for extreme thermolability of amylase 
and thermostability of protease in A. hydrophila PC5 are not understood at present. Thermostable proteases and thermolabile amylases have been reported from some psychrotrophs $(1,19)$.

The inhibition of protease by metal chelating agents such as EDTA and stimulation by $\mathrm{Fe}^{2+}$ confirms it to be a metalloprotease. Since iodoacetamide inactivated both enzymes it indicated that the enzymes may have a thiol groups at their active sites. Unlike many metalloproteases, the protease of strain PC5 was inhibited by $10 \mathrm{mM} \mathrm{Zn}^{2+}$. Recently, the inhibition of metalloprotease by $\mathrm{Zn}^{2+}$ at concentration as low as $1 \mathrm{mM}$ in Clostridium bifermentans (10) was reported.

It was reported that pathogenic strains of $A$. hydrophila produce three types of proteases: a) heat-labile serine protease, a heat-stable metalloprotease and an elastase (15). However, the present strain PC5 produced a single heat stable metalloprotease. The substrate-impregnated gel electrophoresis data and DEAEcellulose chromatography profile confirmed these findings. Whether the absence of other two types of proteases may be responsible for its nonpathogenicity is not known at present.

In conclusion, $A$. hydrophila $\mathrm{PC} 5$ produced an active amylase and a protease in good yields at $\leq 20^{\circ} \mathrm{C}$. Such enzyme complex will be of great use in beer and other starch-based industries. The resistance of protease to heat and detergents (SDS) and activity at even pH 12.0 (about 60\% activity) makes it a suitable biocatalyst in the detergent industry. Further, its nonpathogenic nature, good growth at $<10^{\circ} \mathrm{C}$ and production of enzymes on a wide variety of substrates make it a promising organism for biodegradation of organic wastes at low temperature areas.

The microorganisms that produce two or more enzymes form excellent model systems to understand the expression of two or more genes simultaneously by the same inducer. Although A. hydrophila PC5 contained plasmids, as revealed by $1 \%$ agarose gel electrophoresis (data not shown), experiments with plasmid curing agents such as SDS have shown that the enzymes are chromosomal borne. Further studies are required at the molecular level to understand the regulation of these enzymes in the present strain.

The authors are thankful to Dr. R. V. Swamy, Director, and Shri K. M. Rao, Jt. Director, DRDE, Gwalior, India for providing laboratory facilities. The help rendered by Dr. B. D. Parasher for determination of the pathogenicity of the strain to fish and snails and by Shri. Lokeshwar Reddy and Pancham Singh in the preparation of the illustrations is kindly acknowledged.

\section{REFERENCES}

1) Adams, D. M., Barach, J. T., and Speck, M. L., Heat resistant proteases produced in milk by psychrotrophic bacteria of dairy origin. J. Dairy Sci., 58, 828-834 (1975).

2) Allen, B. and Stevenson, R. M. W., Extracellular virulence factors of Aeromonas hydrophila in fish infections. Can. J. Microbiol., 27, 1114-1122 (1981).

3) Amborski, R. L., Borall, R., and Thune, R. L., Effects of short term storage on recovery of protease from extracellular products of Aeromonas hydrophila. Appl. Environ.Microbiol., 48, 456458 (1984). 
4) Blackshear, P. J., Systems for polyacrylamide gel electrophoresis. In Methods in Enzymology, Vol. 104, ed. by Jacoby, W. B., Academic Press, New York (1984) p. 237-255.

5) Dahle, K. H., The purification and some properties of two Aeromonas proteases. Acta Pathol. Microbiol. Scand. Sect. B, 79, 726-738 (1971).

6) Gobius, K. S. and Pemberton, J. M., Molecular cloning, characterization and nucleotide sequence of an extracellular amylase gene from Aeromonas hydrophila. J. Bacteriol., 170, 1325-1332 (1988).

7) Griffiths, M. W., Phillips, J. D., and Muir, D. D., Thermostability of proteases and lipases from a number of species of psychrotrophic bacteria of dairy origin. J. Appl. Bacteriol., 50, 289-303 (1981).

8) Hug, D. H. and Hunter, J. K., Effect of temperature on urocanase from a psychrophile, Pseudomonas putida. Biochemistry, 13, 1427-1431 (1974).

9) Long, S., Mothibelli, M. A., Robb, F. T., and Woods, D. R., Regulation of extra-cellular alkaline protease activity by histidine in a collagenolytic Vibrio alginolyticus strain. J. Gen. Microbiol., 127, 193-199 (1981).

10) Macfarlane, G. T. and Macfarlane, S., Physiological and nutritional factors affecting synthesis of extracellular metalloproteases by Clostridium bifermentans NCTC 2914. Appl. Environ. Microbiol., 58, 1195-1200 (1992).

11) Morita, R. Y., Psychrotrophic bacteria. Bacteriol. Rev., 39, 144-167 (1975).

12) Pansare, A. C., Venugopal, V., and Lewis, N. F., A note on nutritional influence on extra-cellular protease synthesis. J. Appl. Bacteriol., 58, 101-104 (1985).

13) Priest, F. G., Extra-Cellular Enzymes. Aspects of Microbiology, Vol. 9, Van Nostrand Reinhold (UK) Company Ltd., Wokingham, Berkshire, U.K. (1984), p. 1-79.

14) Ramesh, M. V. and Lonsane, B. K., Ability of solid state fermentation technique to significantly minimize catabolic repression of $\alpha$-amylase production by Bacillus licheniformis M27. Appl. Microbiol. Biotechnol., 35, 591-593 (1991).

15) Rivero, O., Anguita, J., Matoes, D., Paniagua, C., and Naharro, G., Cloning and characterization of an extracellular temperature-labile serine protease from Aeromonas hydrophila. FEMS Microbiol. Lett., 81, 1-8 (1991).

16) Shimagaki, H., Takeuchi, K., Nishino, T., Ohdera, M., Kudo, T., Ohba, K., Iwama, M., and Irie, M., Purification and properties of a novel surface active agent and alkaline resistant protease from Bacillus sp. Agric. Biol. Chem., 9, 2251-2258 (1991).

17) Slabospitskaya, A. T., Krymovskaya, S. S., and Reznik, S. R., Enzymic activity of bacilli perspective for inclusion into composition of biopreparation. Microbiol. Zn., 52, 9-13 (1990).

18) Stark, J. R., Theresa, B., and Priest, F. G., Characterization of extra-cellular $\alpha$ - and $\beta$-amylases from Bacillus megaterium. FEMS Microbiol. Lett., 15, 295-298 (1982).

19) Stepanaik, L., Fox, P. F., and Daly, C., Isolation and general characterization of a heat stable proteinase from Pseudomonas fluorescens AFT36. Biochim. Biophys. Acta, 717, 376-383 (1982).

20) Whooley, M. A., O'Callaghan, J. A., and McLoughlin, A. J., Effect of substrate on the regulation of exoprotease production by Pseudomonas aeruginosa ATCC 10145. J. Gen. Microbiol., 129, 981988 (1983).

21) Witter, L. D., Psychrophilic bacteria-A review. J. Dairy Sci., 44, 983-1015 (1961). 